\title{
Air-Steam Gasification of Nigerian Lignite Coals for Hydrogen and Syngas Production
}

\section{Olagoke Oladokun}

Universiti Teknologi Malaysia

Bemgba B. Nyakuma ( $\square$ bnbevan2@live.utm.my )

Universiti Teknologi Malaysia https://orcid.org/0000-0001-5388-7950

\section{Research}

Keywords: Air-Steam, Gasification, Lignite Coal, Hydrogen, Syngas, Nigeria

Posted Date: September 8th, 2020

DOI: https://doi.org/10.21203/rs.3.rs-70860/v1

License: (c) (1) This work is licensed under a Creative Commons Attribution 4.0 International License. Read Full License 


\title{
Air-Steam Gasification of Nigerian Lignite Coals for Hydrogen and Syngas Production
}

\author{
Olagoke Oladokun $^{1,2}$, Bemgba B. Nyakuma ${ }^{1 *}$ \\ ${ }^{1}$ School of Chemical and Energy Engineering, Faculty of Engineering, \\ Universiti Teknologi Malaysia, 81310 Skudai, Johor, Malaysia. \\ ${ }^{2}$ Department of Chemical Engineering, University of Maiduguri, \\ P. M. B. 1069 Bama Road, Maiduguri, Borno State, Nigeria \\ *Correspondence Email: bbnyax1@gmail.com
}

\begin{abstract}
Coal is the fuel that drives most emerging economies. The gasification along with carbon capture and sequestration could ameliorate the harmful effects of coal utilisation. In this study, two recently discovered lignite coals; Obomkpa (BMK) and Ihioma (IHM) were examined for hydrogen and synthesis gas production through air-steam gasification using a non-stoichiometric model simulated in ASPEN Plus. The results showed that $\mathrm{H}_{2}$ production from BMK and IHM was highly sensitive to temperature and air but moderately sensitive to steam during gasification. The optimal operating conditions for BMK and IHM are; temperature $1125{ }^{\circ} \mathrm{C}$ and $1350{ }^{\circ} \mathrm{C}$; equivalence ratio (ER) 0.26 and 0.26 ; steam/carbon ratio (S/C) 2.25 and 2.19, respectively. The optimal gas composition for BMK was; $\mathrm{H}_{2}(0.66), \mathrm{CO}$ (0.18) and $\mathrm{CO}_{2}(0.18)$ mole-fraction, whereas for IHM was; $\mathrm{H}_{2}(0.65), \mathrm{CO}(0.17)$ and $\mathrm{CO}_{2}$ (0.17). The findings indicate that both lignite coals are suitable feedstock for $\mathrm{H}_{2}$ and syngas production.
\end{abstract}

Keywords: Air-Steam, Gasification, Lignite Coal, Hydrogen, Syngas, Nigeria. 


\section{Introduction}

Coal is the solid fossil fuel that birthed the industrial revolution and sustains human civilisation (OECD Working Paper 2012; Freese 2016). It is the most abundant and distributed solid fossil fuel in the world. Hence, coal accounts for over $60 \%$ of all economically recoverable energy resource compared to $19 \%$ and $17 \%$ for petroleum and natural gas (IEA 2018). Besides, coal accounts for over $40 \%$ or 8,200 terawatt-hours (TWh) of the electricity generated annually around the globe. Hence, coal is considered the cornerstone of global electricity and plays a crucial role in the global energy mix (OECD Working Paper 2012). However, over the years, there has been increased objection to the utilisation of coal for power generation due to its adverse effects on the environment (Fallows 2010). Intrinsically, many emerging and developed economies still depend on coal as the fuel that drives growth and sustains development.

One way of ameliorating the adverse effects of coal on the environment is the conversion into environmentally friendly fuels and chemicals such as syngas $\left(\mathrm{H}_{2}+\mathrm{CO}\right)$ with simultaneous carbon dioxide $\left(\mathrm{CO}_{2}\right)$ capture and sequestration. The most widely used process for converting coal into syngas is gasification. Gasification is a thermochemical process in which heat is utilised to convert carbonaceous feedstocks such as biomass, coal and petroleum coke into useful gaseous products and chemicals (Higman and van der Burgt 2008; Speight 2012). Over the years, numerous empirical studies have investigated coal gasification for syngas and synthetic natural gas (SNG) production. Recently, the mathematical modelling and simulation of coal gasification using the non-stoichiometry model and Gibbs free analysis can satisfactorily predict the product gas yield and composition.

Duan et al. (2015) simulated coal gasification with slag in the presence of steam in a blast furnace with a constraint on mass and energy for heat recovery. The study showed that clean syngas could be effectively recovered from the process. The flow processes for 
pyrolysis, gasification, and combustion units from ASPEN Plus were integrated into the Texaco coal gasifier for the comprehensive conversion of coal into product gas. The simulation successfully predicted the product gas composition, carbon conversion, and gasification temperatures (Kong et al. 2013). Preciado et al. (2012) investigated the steam and oxy-fuel gasification of coal from Colombia through steady-state mathematical modelling and simulation. The findings showed that the ratio of oxygen to carbon is a crucial factor in the process. Similarly, the fixed bed catalytic coal gasification process of Exxon was successfully modelled and simulated, and the kinetic analysis result validated experimentally by Jang et al. (2013).

The ASPEN simulation of the catalytic co-gasification of coal and organic wastewater with an alkaline $\mathrm{pH}$ was investigated by Xiao et al. (2019) using a fluidised bed gasifier. The findings revealed that the optimal ratio of steam to coal, temperature, and equivalence ratio for the process. The co-firing of coal and dried sewage sludge (DSS) through gasification was examined in a dual-step gasification reactor comprising a fluidised bed and tar-cracking reactors (Jeong et al. 2019). The findings showed that the product gas composition improved with increasing mixing ratio of coal and DSS. Overall, the review of the literature indicates that modelling and simulation of various ranks of coal can be effectively utilised to predict product gas, yield, and composition.

Over the years, massive new deposits of coal have been discovered in Nigeria. As a result, there is renewed attention in converting the nation's coal resources into chemicals, industrial materials, and electricity (Nyakuma and Jauro 2016; Ryemshak and Jauro 2013; Nyakuma 2016). The nation's proven coal reserves are estimated at 640 million tonnes, whereas the projected resources are approximately 2.8 billion tonnes (Chukwu et al. 2016). The distribution of Nigeria's reserves of coal are comprised of lignite (12\%), sub-bituminous (49\%), and bituminous (39\%), which are distributed across the six geopolitical zones (Obaje 
2009). Despite the abundant resources in the country, industrial utilisation of coal is virtually non-existent (Nyakuma 2019; Ohimain 2014).

Amidst the growing calls for energy generation from renewable and sustainable sources, cleaner technologies are required for the utilisation of Nigeria's coal resources (Oboirien et al. 2018; Amoo 2015). The gasification of low-ranked coals such as lignite is a potential alternative to pulverised coal combustion (PCC) widely utilised for power generation. However, there is currently no study in the literature on the gasification of lignite coals from Nigeria. Furthermore, the product gas yield, composition, and optimal operating conditions for the gasification of Nigerian lignite coals are yet to be determined by researchers in the field.

Therefore, this study presents novel findings on the modelling and simulation of airstream gasification of two newly discovered lignite coals from Obomkpa (BMK) and Ihioma (IHM) using ASPEN Plus. Likewise, the hydrogen and syngas production potential of BMK and IHM coals are investigated based on empirical data on ultimate, proximate, and sulphanal analyses. Lastly, the sensitivity and optimisation analyses of the lignite samples were performed in ASPEN Plus to determine the optimal operating gasification conditions for future application.

\section{Theory and Methods}

\subsection{Theory}

The process was modelled and simulated by reducing the Gibbs free energy of all the constituents involved in the primary gasification reactions. Typically, these reactions consist of water gas shift, steam reforming, and methanation. The Gibbs free energy for the $N$ species $(i=1 \ldots N)$ is based on the fundamental equation presented as (Basu 2010): 


$$
G_{\text {total }}=\sum_{i=1}^{N} n_{i} \Delta G_{f . i}^{0}+\sum_{i=1}^{N} n_{i} R T \ln \left[\frac{n_{i}}{\sum n_{i}}\right]
$$

Where the term $\Delta G_{f . i}^{0}$ denotes the Gibbs free energy for the formation of the $i$ th species at standard pressure. The minimisation of the objective function was performed by solving $n_{i}$ in Eq. 1. The carbon content deduced from ultimate analysis must equal the total carbon in the mixture of gases. Therefore, the $j$ th component is expressed by the relation;

$$
\sum_{i=1}^{N} a_{i, j} n_{i}=A_{j}
$$

Where $a_{i, j}$ represents the atoms of the $j$ th element of the $i$ th species, whereas $A_{j}$ is the total amount of atoms of the $j$ element in going to the reactor. Based on the Lagrange multiplier, the term $\lambda$ methods is given by the relation:

$$
L=G_{\text {total }}-\sum_{i=1}^{N} \lambda_{j}\left(\sum_{i=1}^{N} a_{i, j} n_{i}-A_{j}\right)
$$

Therefore, the final values can be deduced by substituting Eq. 3 into Eq. 1;

$$
\frac{\partial L}{\partial n_{i}}=\frac{\Delta G_{f . i}^{0}}{R T}+\sum_{i=1}^{N} \ln \left(\frac{n_{i}}{n_{\text {total }}}\right)+\frac{1}{R T} \sum_{j=1}^{K} \lambda_{j}\left(\sum_{i=1}^{N} a_{i, j} n_{i}\right)
$$

In this study, the critical products considered were $\mathrm{H}_{2}, \mathrm{CO}, \mathrm{CO}_{2}, \mathrm{CH}_{4}, \mathrm{C}$ (graphite) and excess steam during the reforming reaction. Besides, the prospective ancillary constituents identified were; ethane, ethylene, acetylene, and ethanol not previously reported in the literature (Vagia and Lemonidou 2007). In practice, the secondary products are considered precursors of coke despite their presence in minor concentration. Conversely, the high content of carbon in the constituent reactions was taken into account in this study. The 
steam reforming of coal is governed primarily by the following reactions; water gas shift, steam reforming, and methanation, which are presented as (Liu et al. 2013):

$$
\begin{gathered}
\mathrm{C}_{\mathrm{x}} \mathrm{H}_{\mathrm{y}} \mathrm{O}_{\mathrm{z}}+(\mathrm{x}-\mathrm{z}) \mathrm{H}_{2} \mathrm{O} \leftrightarrow \mathrm{xCO}+(\mathrm{x}+\mathrm{y} / 2-\mathrm{z}) \mathrm{H}_{2} \\
\mathrm{CO}+\mathrm{H}_{2} \mathrm{O} \leftrightarrow \mathrm{CO}_{2}+\mathrm{H}_{2} \\
\mathrm{CO}+3 \mathrm{H}_{2} \leftrightarrow \mathrm{CH}_{4}+\mathrm{H}_{2} \mathrm{O}
\end{gathered}
$$

Combining Eq. 5 and Eq. 6 gives the overall reaction for coal steam reforming in this study;

$$
\mathrm{C}_{\mathrm{x}} \mathrm{H}_{\mathrm{y}} \mathrm{O}_{\mathrm{z}}+(2 \mathrm{x}-\mathrm{z}) \mathrm{H}_{2} \mathrm{O} \leftrightarrow \mathrm{xCO}_{2}+(2 \mathrm{x}+\mathrm{y} / 2-\mathrm{z}) \mathrm{H}_{2}
$$

Lastly, the product gas and yield of the reaction are comprised of $\mathrm{H}_{2}, \mathrm{CO}, \mathrm{CO}_{2}$ and $\mathrm{CH}_{4}$, as computed from to Eq. (8).

\subsection{Process Description}

The simulation of the coal gasification process was developed in ASPEN software. The process flow sheet depicted in Figure 1 consists of a three-model unit: the RYield (DECOMP), RGibbs (BURN), Separator (SEPARATE) and Calculator unit.

Figure 1. Flowsheet of Lignite Coal Gasification in ASPEN

The RYield was used to convert the proximate, ultimate, and sulphanal analyses of the lignite coals (presented in Table 1) into potential chemical compounds. On the other hand, the Calculator module was employed to normalise the output of the RYield comprising; water $\left(\mathrm{H}_{2} \mathrm{O}\right)$, ash, carbon $(\mathrm{C})$, hydrogen $\left(\mathrm{H}_{2}\right)$, nitrogen $\left(\mathrm{N}_{2}\right)$, chlorine $\left(\mathrm{Cl}_{2}\right)$, sulphur $(\mathrm{S})$ and oxygen $\left(\mathrm{O}_{2}\right)$. The outlined components serve as the inlet components for the RGibbs or gasification unit. The Gibb free equilibrium analysis was used to compute the moles of each component present in the reactor at the specified operating conditions. Apart from the inlet components from the RYield, the products in the RGibbs consist of all potential gasification gas products, namely; hydrogen $\left(\mathrm{H}_{2}\right)$, carbon monoxide $(\mathrm{CO})$, carbon dioxide $\left(\mathrm{CO}_{2}\right)$, methane $\left(\mathrm{CH}_{4}\right)$ and 
ethylene $\left(\mathrm{C}_{2} \mathrm{H}_{4}\right)$. The product of the RGibbs unit was then separated in the stream separator into gases and solid products of the gasification process.

Table 1. Proximate, Ultimate and Sulphanal analysis of BMK and IHM (Nyakuma et al. 2017)

\section{Results and Discussion}

\subsection{Obomkpa (BMK) coal analysis}

\subsubsection{Effect of temperature on gas composition}

The effect of temperature on the product gas yield and composition of $\mathrm{H}_{2}, \mathrm{CO}_{2}, \mathrm{CO}$, and $\mathrm{CH}_{4}$ during the gasification of $\mathrm{BMK}$ is presented in Figure 2. For the simulation, the air (oxygen) and steam values were fixed at $10 \mathrm{kmol}$ and $1500 \mathrm{~kg} / \mathrm{h}$, respectively. The findings indicate that the composition of $\mathrm{H}_{2}$ rapidly increases with temperature from zero at $200{ }^{\circ} \mathrm{C}$ to the maximum mole-fraction of 0.71 at $650{ }^{\circ} \mathrm{C}$. Similarly, the composition of CO increased from $0.0-0.07$ in the temperature range from $200{ }^{\circ} \mathrm{C}$ to $600{ }^{\circ} \mathrm{C}$, whereas the $\mathrm{CO}_{2}$ and $\mathrm{CH}_{4}$ decreased from $0.61-0.22$ and $0.35-0.0$, respectively (Oladokun et al. 2016). The findings suggest that the temperature range from $200{ }^{\circ} \mathrm{C}$ to $600{ }^{\circ} \mathrm{C}$ favours all three major reactions reforming reactions. In addition, it accounts for why the composition of $\mathrm{CH}_{4}$ is higher than $\mathrm{CO}$ (Oladokun et al. 2017). However, a further increase in temperature from $600{ }^{\circ} \mathrm{C}$ to 1600 ${ }^{\circ} \mathrm{C}$ resulted in a decline in $\mathrm{H}_{2}$ and $\mathrm{CO}_{2}$ compositions to 0.63 and 0.14 mole-fraction or $3 \%$ and $2.5 \%$, respectively.

Figure 2. BMK Product Gas Composition variation with Temperature

However, the CO increased steadily from 0.07 to 0.22 mole-fraction. This can be explained by the increase in temperature, which favours the steam reforming reaction and the reversible methanation reaction resulting in more $\mathrm{CO}$ production. Lastly, the optimal operating conditions for the BMK gasification were determined. The optimal temperature is defined as the lowest temperature when $\mathrm{CO}$ is greater and/or equal to $\mathrm{CO}_{2}$. For the 
gasification of BMK, the optimal temperature deduced at ER (0.26), S/C (2.3), Pressure (1 bar) is $1125{ }^{\circ} \mathrm{C}$ based on Figure 2 . Hence, the optimal gas composition at the optimum temperature was; $\mathrm{H}_{2}(0.66), \mathrm{CO}(0.17), \mathrm{CO}_{2}(0.17)$ and $\mathrm{CH}_{4}(0.0)$.

\subsubsection{Effect of $\mathrm{ER}$ and $\mathrm{S} / \mathrm{C}$ on $\mathrm{H}_{2}$ composition}

Figure 3 presents the effects of ER and $\mathrm{S} / \mathrm{C}$ on the $\mathrm{H}_{2}$ composition (Mole-fraction) at the simulated temperature and pressure conditions of $1100{ }^{\circ} \mathrm{C}$ and $1 \mathrm{bar}$, respectively.

Figure 3. BMK $\mathrm{H}_{2}$ Mole-fraction variation with $\mathrm{ER}$ and $\mathrm{S} / \mathrm{C}$

The findings indicate that the composition of $\mathrm{H}_{2}$ decreased at higher equivalence ratio (ER) for all steam to carbon $(\mathrm{S} / \mathrm{C})$ ratios. In addition, the profile revealed that changes to the $\mathrm{S} / \mathrm{C}$ at ER $1.05 \mathrm{had}$ an insignificant effect on the $\mathrm{H}_{2}$ composition. The ER at 1.05 is the maximum range for BMK gasification and the beginning of combustion, as observed by the absence of $\mathrm{H}_{2}$. Furthermore, the composition of $\mathrm{H}_{2}$ increased with the increase in steam due to the steam reforming reaction. However, the percentage $\mathrm{H}_{2}$ decreased with an increase in $\mathrm{S} / \mathrm{C}$ for all the ER considered. The optimal S/C determined at 2.25 was the point at which the sensitivity of the $\mathrm{H}_{2}$ composition was insignificant. Therefore, the $\mathrm{H}_{2}$ composition at the optimum $\mathrm{S} / \mathrm{C}$ of 2.25 was 0.74 at the ER of 0.0 for the maximum value, whereas the minimum $\mathrm{H}_{2}$ was 0.0 at the ER of 1.05 . The ER for gasification occurs at values above 0.2 but below 1.0. Therefore, the range of $\mathrm{H}_{2}$ composition is 0.66 at ER 0.26 and 0.54 at the ER of 0.52 .

\subsubsection{Effect of $\mathrm{S} / \mathrm{C}$ on $\mathrm{H}_{2}$ Composition}

The profile of $\mathrm{H}_{2}$ composition with S/C and ER at a constant temperature of $1100{ }^{\circ} \mathrm{C}$ and pressure of 1 bar is presented in Figure 4. The increase in steam caused a corresponding increase in $\mathrm{H}_{2}$ production for all the ER except for ER higher than 0.92. As explained earlier, 
$\mathrm{H}_{2}$ will not be produced when the value of ER is at 0.92 despite an increase in steam. The sensitivity of $\mathrm{H}_{2}$ composition to $\mathrm{S} / \mathrm{C}$ was appreciable from 0 till 2.25. However, the percentage increase was subsequently constant with further increase in S/C for all ER values.

Figure 4. $\quad B M K \mathrm{H}_{2}$ Mole-fraction variation with $\mathrm{SC}$ and $\mathrm{ER}$

Based on the comparison of the profiles for all ER at S/C of 2.25, the composition of $\mathrm{H}_{2}$ decreased with increasing ER. The optimum ER was determined at the least significant percentage decrease, which was between 0.26 and 0.39 . The composition of $\mathrm{H}_{2}$ at the optimum range of ER $(0.26-0.39)$ was $0.66-0.61$.

\subsection{Ihioma (IHM) coal analysis}

\subsubsection{Effect of temperature on gas composition}

Figure 5 shows the profile of the gas product composition of IHM gasification with temperature, Air at $10 \mathrm{kmol}$ and Steam at $2000 \mathrm{~kg} / \mathrm{h}$. The temperature profile is divided into two regions beginning with the rapid increase in $\mathrm{H}_{2}$ production $\left(200{ }^{\circ} \mathrm{C}\right.$ to $\left.650{ }^{\circ} \mathrm{C}\right)$ and the region of significant $\mathrm{CO}$ production $\left(650{ }^{\circ} \mathrm{C}\right.$ to $\left.1600{ }^{\circ} \mathrm{C}\right)$.

Figure 5. IHM Product Gas Composition variation with Temperature

The first region was characterised by the three gasification reactions: steam reforming, water gas shift, and methanation reactions. Similarly, the second region experienced similar effects; however, the water shift and methanation reactions favoured the backward reaction of the reversible reaction. The gas compositions generated from the first region showed that the $\mathrm{H}_{2}$ mole-fraction increased from 0.03 to 0.71 , whereas the mole fraction of $\mathrm{CO}$ was 0.0 in this region until $500{ }^{\circ} \mathrm{C}$ but increased to 0.05 at $650{ }^{\circ} \mathrm{C}$.

The composition of $\mathrm{CO}_{2}$ and $\mathrm{CH}_{4}$ in the region from $200{ }^{\circ} \mathrm{C}$ to $650{ }^{\circ} \mathrm{C}$ showed a rapid decrease in composition compared to the rapid increase in $\mathrm{H}_{2}$ composition. Similarly, the 
$\mathrm{CO}_{2}$ decreased from 0.62 mole-fraction to 0.24 , whereas the $\mathrm{CH}_{4}$ decreased from 0.33 to 0.0 . The second region from $650{ }^{\circ} \mathrm{C}$ to $1600{ }^{\circ} \mathrm{C}$ showed a steady rise in the $\mathrm{CO}$ composition from 0.05 to 0.20 , whereas the compositions of $\mathrm{H}_{2}, \mathrm{CO}_{2}$, and $\mathrm{CH}_{4}$ decreased to $0.63,0.16$, and 0.0 , respectively. Hence, the optimum temperature for IHM gasification was $1350{ }^{\circ} \mathrm{C}$, which was determined when the minimum temperature of $\mathrm{CO}$ was above and/or equal to $\mathrm{CO}_{2}$. The optimal gas composition at these conditions was $\mathrm{H}_{2}(0.65), \mathrm{CO}(0.17), \mathrm{CO}_{2}(0.17)$, and $\mathrm{CH}_{4}$ $(0.0)$.

\subsubsection{Effect of ER and S/C on $\mathrm{H}_{2}$ Composition}

Figure 6 presents the profile of $\mathrm{H}_{2}$ composition with the variation in ER for IHM at the simulated temperature of $1200{ }^{\circ} \mathrm{C}$ and pressure of 1 bar. As observed, the composition of $\mathrm{H}_{2}$ decreased with increasing ER but increased with S/C.

Figure 6. $\quad \mathrm{H}_{2}$ Mole-fraction variation with ER and S/C

Furthermore, the results showed that the composition of $\mathrm{H}_{2}$ became zero at the ER gasification limit of 1.06 for all the S/C values considered in the study. The optimum S/C from the profile was 2.19 and determined from the first least significant percentage change. The composition of $\mathrm{H}_{2}$ was in the range from 0.64 to 0.05 for the ER range between 0.26 and 0.93 during gasification and the profile of $\mathrm{H}_{2}$ composition at an $\mathrm{S} / \mathrm{C}$ of 2.19.

\subsubsection{Effect of $\mathrm{S} / \mathrm{C}$ and $\mathrm{ER}$ on $\mathrm{H}_{2}$ Composition}

The composition of $\mathrm{H}_{2}$ at the simulated temperature of $1200{ }^{\circ} \mathrm{C}$ and pressure of $1 \mathrm{bar}$ is presented in Figure 7. As observed, the $\mathrm{H}_{2}$ composition increased with increasing S/C but decreased with increasing ER.

Figure 7. $\mathrm{H}_{2}$ Mole-fraction variation with $\mathrm{S} / \mathrm{C}$ and $\mathrm{ER}$ 
The limiting S/C was 2.19 for all ER values examined in the study. The S/C limit was determined at the point where further supply in steam did not result in any significant increase in the production of $\mathrm{H}_{2}$ via the steam reforming reaction. Based on the optimum $\mathrm{S} / \mathrm{C}$ of 2.19 determined for IHM earlier, the $\mathrm{H}_{2}$ composition decreased from 0.64 to 0.05 at the ER values of 0.26 and 0.93 , respectively. However, this does not include the values of ER greater than or equal to one, which represents combustion. The ER limit is between 0.26 and 0.53 , and the optimum ER is determined as 0.26 .

\section{Conclusion}

The air-steam gasification of two newly discovered lignite coals from Obomkpa (BMK) and Ihioma (IHM) in Nigeria was successfully modelled in ASPEN. For the gasification process, a non-stoichiometric model was developed based on a combination of model units and the Gibbs free energy reactor (RGibbs). The proposed ASPEN model was used to investigate the hydrogen and syngas potential of BMK and IHM. The results showed that BMK and IHM are highly sensitive to temperature and equivalence ratio (ER) but only moderately sensitive to steam/carbon $(\mathrm{S} / \mathrm{C})$ ratio. The optimal gasification temperature for maximum hydrogen and syngas production at minimum $\mathrm{CO}_{2}$ production was $1125{ }^{\circ} \mathrm{C}$ for BMK and $1350{ }^{\circ} \mathrm{C}$ for IHM. The gas composition at the optimal operating conditions showed higher $\mathrm{H}_{2}$ values (or $26 \%$ increase) compared to $\mathrm{CO}$ and $\mathrm{CO}_{2}$ for the samples. Overall, the result showed that BMK and IHM are suitable feedstock for the production of hydrogen and syngas through gasification. 


\section{Declarations section}

\section{Availability of data and materials}

The authors hereby declare that all the data used in this manuscript is ours and provided within the manuscript except otherwise referenced thereof.

\section{Competing interests}

The authors hereby declare that there are ZERO competing.

\section{Funding}

The authors received ZERO funding for this project and manuscript.

\section{Authors' contributions}

Olagoke Oladokun - Original Manuscript Writing, Mathematical Modelling, Data Analysis;

Bemgba B. Nyakuma - Original Manuscript Writing, Editing, Fact Checking, Formatting and Submission.

\section{Acknowledgement}

The authors wish to gratefully acknowledge the Centre of Hydrogen Energy and the Institute of Future Energy at Universiti Teknologi Malaysia (UTM Skudai, Malaysia) and the University of Maiduguri (Maiduguri, Nigeria) for the technical and material support during the project. 


\section{References}

Amoo LM (2015) Computational fluid dynamics simulation of Lafia-Obi bituminous coal in a fluidized-bed chamber for air-and oxy-fuel combustion technologies Fuel 140:178191

Basu P (2010) Biomass Gasification and Pyrolysis: Practical Design and Theory. Academic Press (Elsevier), Burlington MA, USA

Chukwu M, Folayan C, Pam G, Obada D (2016) Characterization of some Nigerian coals for power generation Journal of Combustion 2016

Duan W, Yu Q, Wang K, Qin Q, Hou L, Yao X, Wu T (2015) ASPEN Plus simulation of coal integrated gasification combined blast furnace slag waste heat recovery system Energy Conversion and Management 100:30-36 doi:10.1016/j.enconman.2015.04.066

Fallows J (2010) Dirty coal, clean future The Atlantic 306:64-78

Freese B (2016) Coal: A Human History. Basic Books, New York, New York, United States

Higman C, van der Burgt M (2008) Gasifiation 2nd Edition edn. Gulf Professional Publishing/ Elsevier,

IEA (2018) Market Report Series: Coal 2018. International Energy Agency, Paris, France

Jang D-H, Kim H-T, Lee C, Kim S-H (2013) Kinetic analysis of catalytic coal gasification process in fixed bed condition using Aspen Plus International Journal of Hydrogen Energy 38:6021-6026 doi:10.1016/j.ijhydene.2013.01.167

Jeong YS, Choi YK, Park KB, Kim JS (2019) Air co-gasification of coal and dried sewage sludge in a two-stage gasifier: Effect of blending ratio on the producer gas composition and tar removal Energy 185:708-716 doi:10.1016/j.energy.2019.07.093

Kong X, Zhong W, Du W, Qian F (2013) Three Stage Equilibrium Model for Coal Gasification in Entrained Flow Gasifiers Based on Aspen Plus Chinese Journal of Chemical Engineering 21:79-84 doi:10.1016/s1004-9541(13)60444-9 
Liu S, Chen M, Hu Q, Wang J, Kong L (2013) The kinetics model and pyrolysis behavior of the aqueous fraction of bio-oil Bioresource Technology 129:381-386 doi:10.1016/j.biortech.2012.11.006

Nyakuma B (2016) Physicochemical Characterization and Thermal Analysis of newly discovered Nigerian coals Bulgarian Chemical Communications 48:746 - 752

Nyakuma BB (2019) Physicochemical, Geomineralogical, and Evolved Gas Analyses of Newly Discovered Nigerian Lignite Coals Coke \& Chemistry 62:394-401

Nyakuma BB, Jauro A (2016) Physicochemical Characterization and Thermal Decomposition of Garin Maiganga Coal GeoScience Engineering 62:6-11

Nyakuma BB, Oladokun O, Jauro A, Nyakuma DD (2017) Fuel Characterization of Newly Discovered Nigerian Coals IOP Conference Series: Materials Science and Engineering 217:012012 doi:10.1088/1757-899x/217/1/012012

Obaje NG (2009) Geology and mineral resources of Nigeria vol 120. Lecture Notes in Earth Sciences. $\quad$ Springer, Berlin, Heidelberg, Berlin, Germany. doi:https://doi.org/10.1007/978-3-540-92685-6

Oboirien B, North B, Obayopo S, Odusote J, Sadiku E (2018) Analysis of clean coal technology in Nigeria for energy generation Energy Strategy Reviews 20:64-70

OECD Working Paper (2012) The Global Value of Coal

Ohimain EI (2014) Can Nigeria generate 30\% of her electricity from coal? International Journal of Energy and Power Engineering 3:28-37

Oladokun O, Ahmad A, Abdullah TAT, Nyakuma BB, Kamaroddin MFA, Nor SHM (2017) Biohydrogen production from Imperata cylindrica bio-oil using non-stoichiometric and thermodynamic model International Journal of Hydrogen Energy 42:9011-9023 doi:10.1016/j.ijhydene.2016.05.200 
Oladokun O, Ahmad A, Tuan Abdullah TA, Nyakuma BB, Kamaroddin MFA, Ahmed M, Alkali H (2016) Sensitivity Analysis of Biohydrogen Production from Imperata Cylindrica Using Stoichiometric Equilibrium Model Jurnal Teknologi 78:137-142 doi:10.11113/jt.v78.9577

Preciado JE, Ortiz-Martinez JJ, Gonzalez-Rivera JC, Sierra-Ramirez R, Gordillo G (2012) Simulation of Synthesis Gas Production from Steam Oxygen Gasification of Colombian Coal Using Aspen Plus (R) Energies 5:4924-4940 doi:10.3390/en5124924

Ryemshak SA, Jauro A (2013) Proximate analysis, rheological properties and technological applications of some Nigerian coals International Journal of Industrial Chemistry 4:7

Speight JG (2012) The Chemistry and Technology of Coal. Chemical Industries, Third Edition edn. CRC Press, USA

Vagia E, Lemonidou A (2007) Thermodynamic Analysis of Hydrogen Production via Steam Reforming of Selected Components of Aqueous Bio-oil Fraction International Journal of Hydrogen Energy 32:212-223 doi:10.1016/j.ijhydene.2006.08.021

Xiao X, Wang X, Zheng Z, Qin W, Zhou Y (2019) Catalytic Coal Gasification Process Simulation with Alkaline Organic Wastewater in a Fluidized Bed Reactor Using Aspen Plus Energies 12 doi:10.3390/en12071367 
Figures

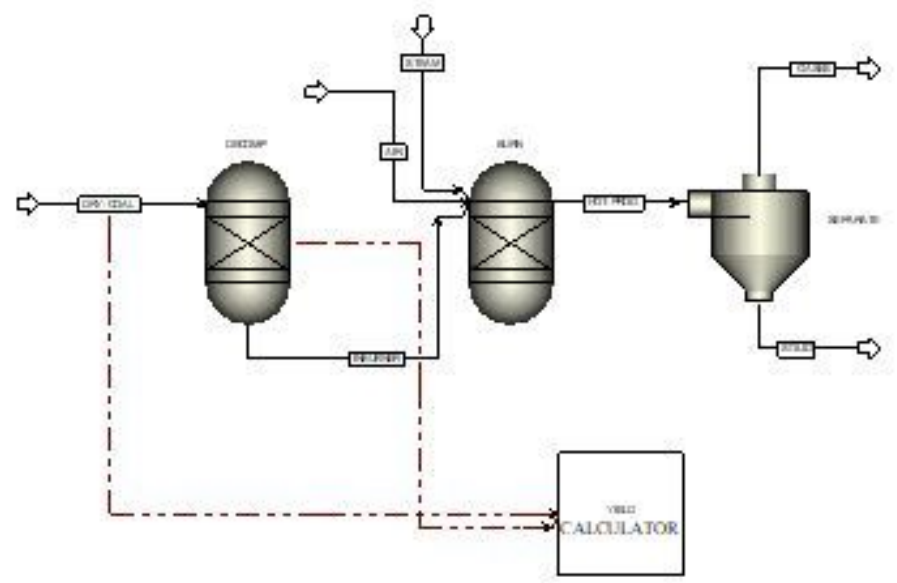

Figure 1

Flowsheet of Lignite Coal Gasification in ASPEN

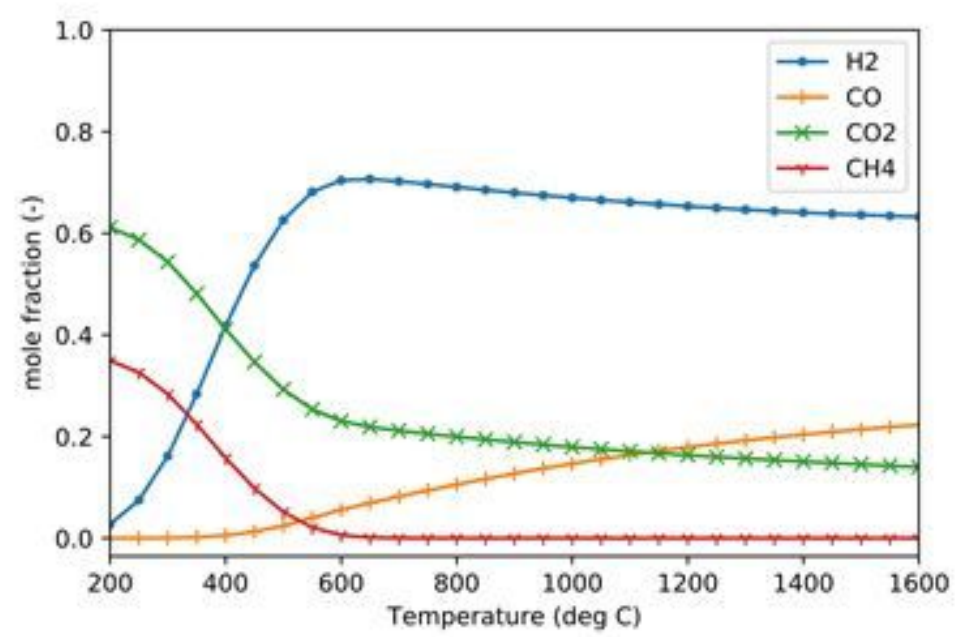

Figure 2

BMK Product Gas Composition variation with Temperature 


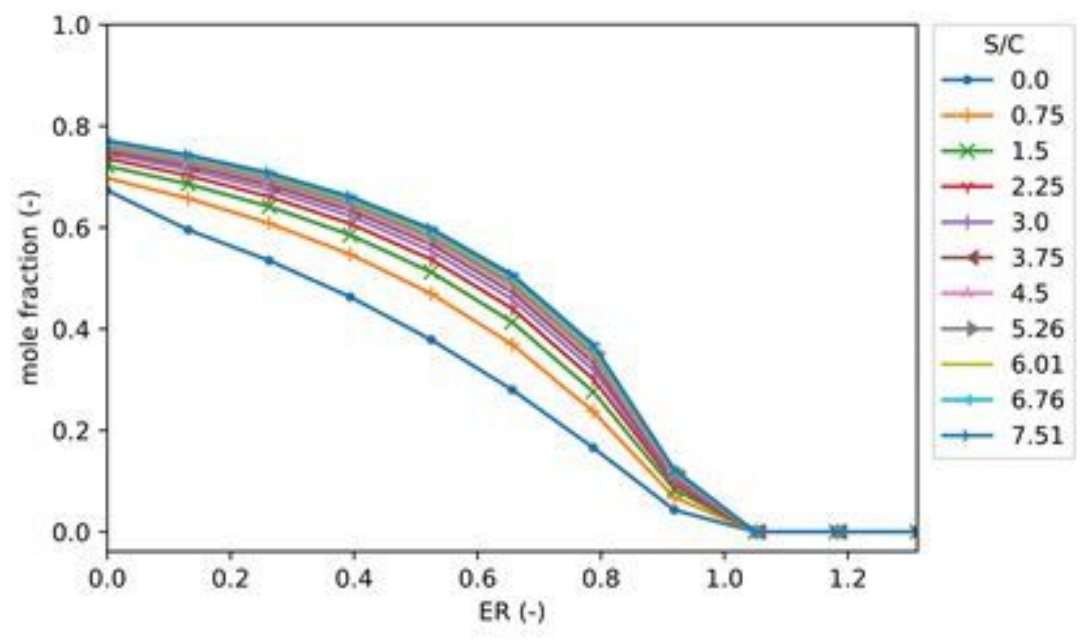

Figure 3

BMK H2 Mole-fraction variation with ER and S/C

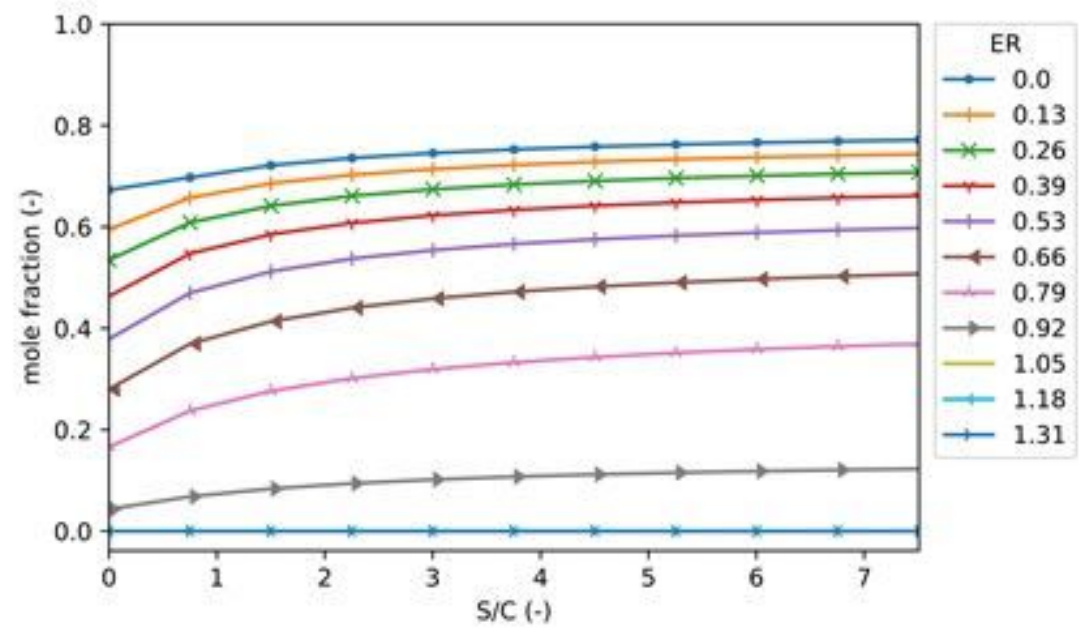

Figure 4

BMK H2 Mole-fraction variation with SC and ER 


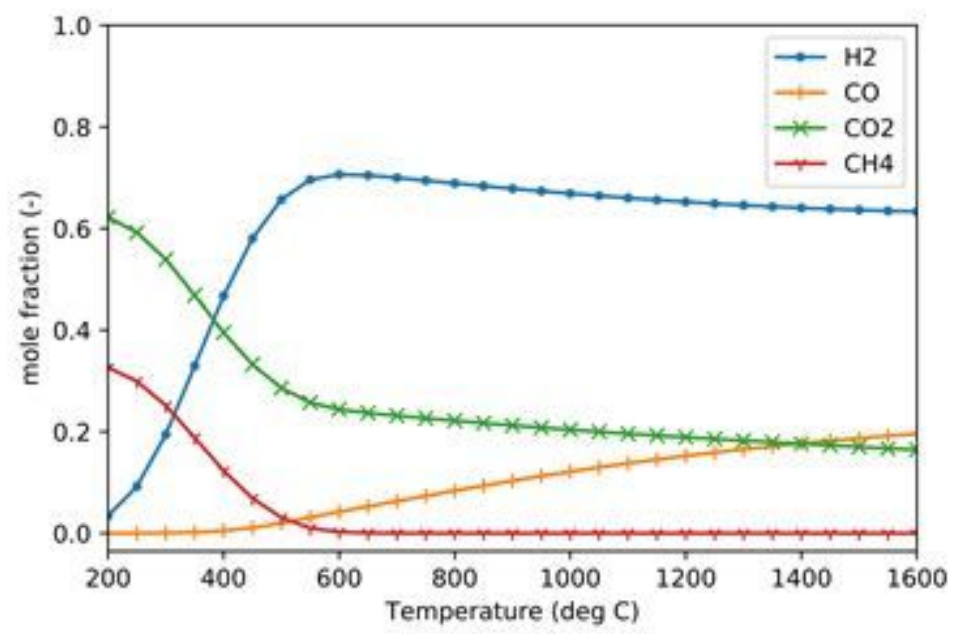

Figure 5

IHM Product Gas Composition variation with Temperature

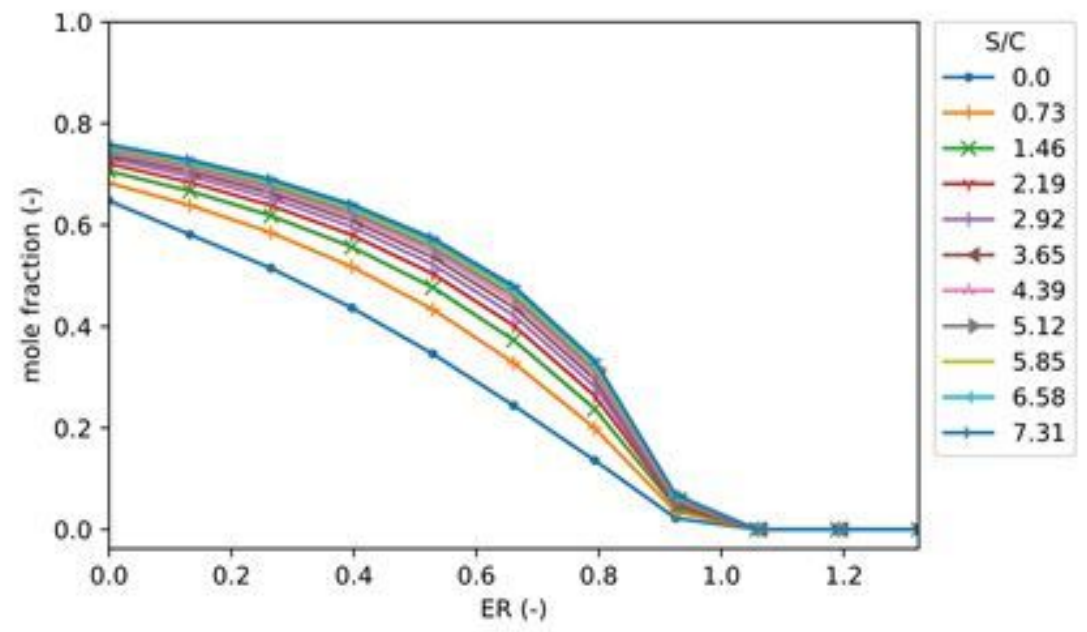

Figure 6

IHM H2 Mole-fraction variation with ER and S/C 


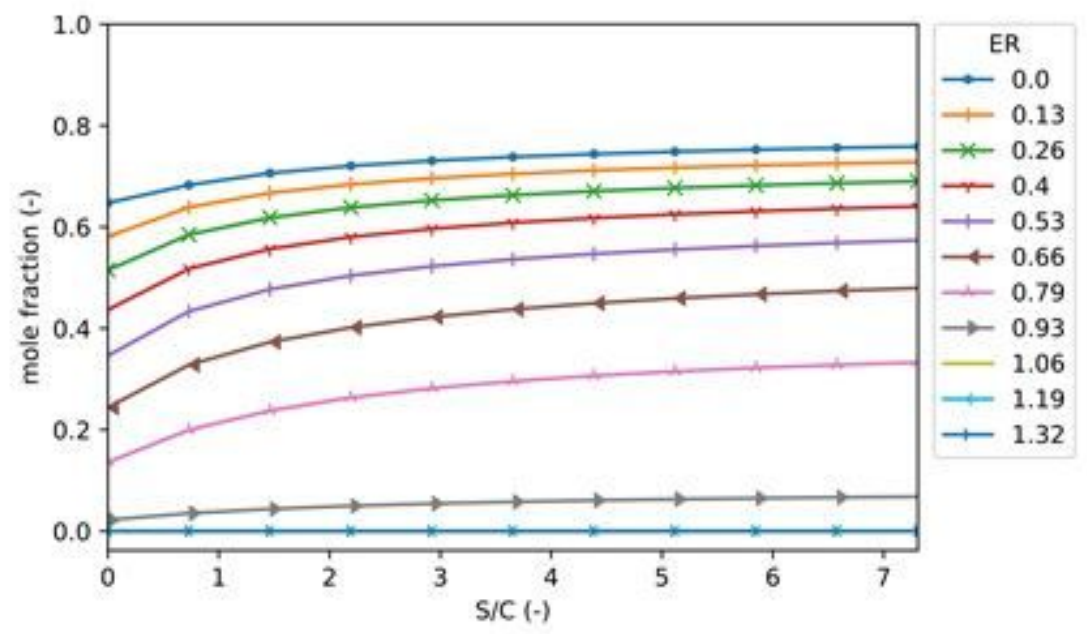

Figure 7

IHM H2 Mole-fraction variation with S/C and ER 